\title{
Overlapping microscale dispersion patterns of meiofauna and microphytobenthos
}

\author{
Gerard F. Blanchard* \\ CNRS-IFREMER, Centre de Recherche en Ecologie Marine et Aquaculture de L'Houmeau BP 5, F-17137 Nieul-Sur-Mer, France
}

\begin{abstract}
Microscale dispersion patterns of meiofauna and microphytobenthos from an oyster pond on the French Atlantic coast were studied through spatial autocorrelation analysis during 2 successive spring periods. Patch size was calculated using correlograms. Both microalgae genera and meiobenthos taxa (except turbellarians in May 1987 and single groups of harpacticoid copepods in April 1988) exhibited patchy distributions. Meiofauna patches ranged from $<4$ to $154 \mathrm{~cm}^{2}$, large diatom $(>40 \mu \mathrm{m})$ patches from $<4$ to $113 \mathrm{~cm}^{2}$ and smaller cell $(<40 \mu \mathrm{m})$ patches from $<4$ to $79 \mathrm{~cm}^{2}$. High variability in patch size was observed between taxa or genera, between years, and a second aggregation level (small patches within large clumps) was shown by harpacticoid copepods. A log-log regression indicated positive spatial associations among meiofauna and microphytobenthos assemblages but not with nanophytobenthos (cells $<40 \mu \mathrm{m}$ ). Furthermore, high complexity among microbiota interactions indicates that no single causative factors may explain observed patterns. When positive significant correlations between meiofauna taxa and microphytobenthos genera occurred, patch size was different. Hence no very close overlap was detected and microphytobenthos was thought to only partially influence meiofauna dispersion. However, selectivity of trophic interactions seems to exist and data support the hypothesis of meiofauna spatial patterns being generated by feeding preferences.
\end{abstract}

\section{INTRODUCTION}

Meiofauna patchiness occurs over a wide range of sediments and natural environments at different spatial scales (Fleeger \& Decho 1987). Mesoscale variability ( $\mathrm{m}$ to $\mathrm{km}$ ) is related to such physical and chemical factors as granulometry and salinity while microscale dispersion $(\mathrm{cm})$ involves organism-microhabitat and inter-organism interactions (Bernstein et al. 1978). Sedimentary heterogeneity, as biogenic structures (Bell et al. 1978, Thistle 1978, Warwick et al. 1986) and microtopography (Decho et al. 1985), may cause smallscale patchiness in meiobenthos, but intraspecific and interspecific interactions are predominant in homogeneous sediments (Heip 1975, Chandler \& Fleeger 1987). Trophic interactions with sediment microbes might be one of the most probable cause for meiobenthos microscale patterns for both nematodes and harpacticoid copepods (Montagna 1984, Decho \& Castenholz 1986, Montagna \& Bauer 1988). Gray

\footnotetext{
- Present address: The University of Texas at Austin, Marine Science Institute, Port Aransas, Texas 78373, USA
}

(1966a, 1967a, 1967b, 1968) and Gray \& Johnson (1970) pioneered research in this field in showing that meiofauna species could actively choose bacterial species and were aggregated in relation to bacteria. Concerning microphytobenthos, there have been very few attempts to assess relationships between meiofauna and microalgae patches but harpacticoid copepod spatial patchiness is apparently a response to diatom patchiness (i.e. chlorophyll a as microalgae biomass estimation) (Decho \& Fleeger 1988).

Microphytobenthos consumption by meiofauna is highly selective and several laboratory experiments have shown that nematodes (Trotter \& Webster 1984, Jensen 1987) and harpacticoid copepods (Vanden Berghe \& Bergmans 1981, Nilsson 1987) discriminate between diatom cells. Furthermore, there is an indication that in situ uptake rates of radiolabeled substrates are related to microbial diets (Carman \& Thistle 1985). Thus meiofauna spatial pattern may be related to feeding preference.

The goal of this study was to demonstrate a specific spatial coupling between microalgae and their herbivorous predators. To test this hypothesis, I analyzed 
their spatial patterns and assessed their patch size using the spatial autocorrelation technique. The present study identified both meiofauna taxa and microphytobenthos genera in an oyster pond on the French Atlantic coast. Identified patterns were correlated to establish in situ significant spatial associations.

\section{MATERIALS AND METHODS}

Microspatial patterns were studied in an oyster pond situated on the West Atlantic coast of France near La Rochelle (Charente-Maritime; $46^{\circ} 10^{\prime} \mathrm{N}, 1^{\circ} 15^{\prime} \mathrm{W}$ ). The area of the pond was $1500 \mathrm{~m}^{2}$ and the water column was about $40 \mathrm{~cm}$ deep. Water was completely replaced every month during spring tide. Two sampling periods were selected, in May 1987 (water temperature = $12.1^{\circ} \mathrm{C}$, salinity $\left.=34.1 \%\right)$ and in April $1988\left(14^{\circ} \mathrm{C}\right.$ and $29.5 \%$ ). For each period, one set of sediment cores was collected using a regular sampler made of 64 cut off plastic syringes (9 $\mathrm{mm}$ inner diameter) arranged in an $8 \times 8$ matrix (Fig. 1). The sampling area was $256 \mathrm{~cm}^{2}$ $(16 \times 16 \mathrm{~cm})$ and each core $\left(0.64 \mathrm{~cm}^{2}\right)$ was placed in the center of a quadrat $\left(4 \mathrm{~cm}^{2}\right)$. Only the first top centimeter of sediment from each syringe was retained for further processing (Coull \& Bell 1979).

The sediment was fixed in $4 \%$ formalin and stained with Rose Bengal. Blanchard's et al. (1988) technique, as modified for the present purpose (Fig. 2), was used to simultaneously separate both meiofauna and mi-

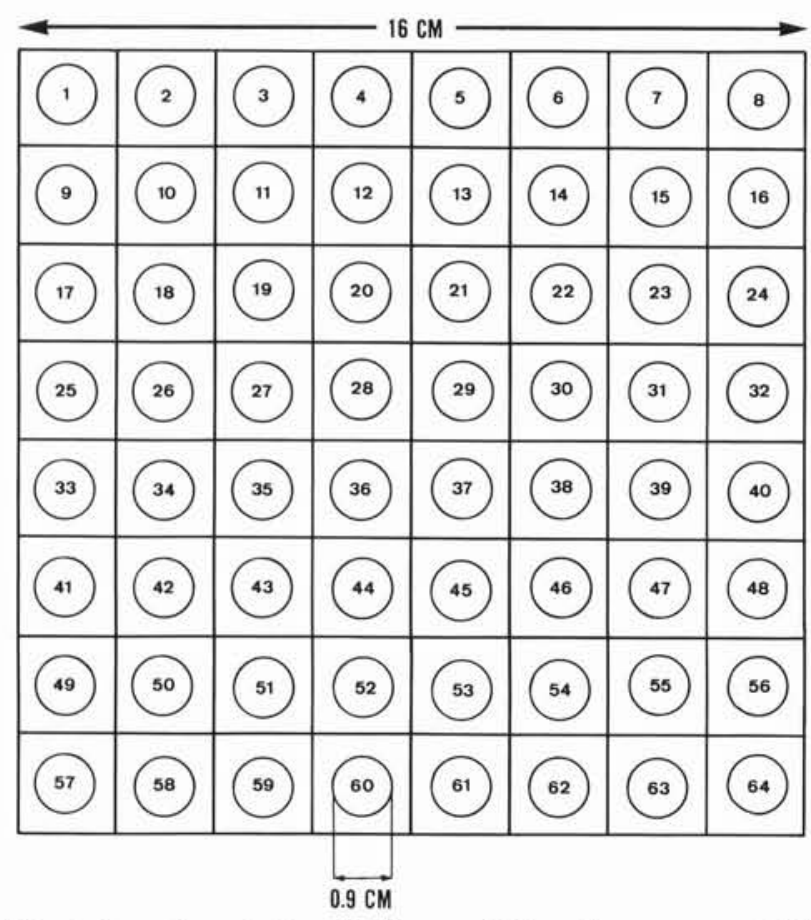

Fig. 1. Sampling design. Total area: $256 \mathrm{~cm}^{2}$; core area: 0.64 $\mathrm{cm}^{2}$ crophytobenthos from the same sediment cores. This method is based upon differential centrifugation in the colloidal silica-gel Ludox HS- $40 \%$ and is designed to retain organisms and algal cells in the supernatant fraction. Meiofauna and microphytes were then isolated by filtering the supernatant Ludox through a 40 $\mu \mathrm{m}$ sieve. Meiofauna counting was executed to major meiofauna taxa and the harpacticoid copepods ontogenic stages (nauplii, copepodites). According to their dominance, 4 harpacticoid copepods working groups were recognized: Canuella sp., cletodids, ectinosomatids and diosaccids (species related in body shape with the family Cletodidae, Ectinosomatidae and Diosaccidae, respectively). Large microalgae were enumerated in a settling chamber using a phase contrast microscope. Six diatom genera (Surirella, Gyrosigma, Pleurosigma, Nitzschia, Amphora, Melosira), total pennate diatoms and microphytobenthos as a whole have been counted. Pleurosigma and

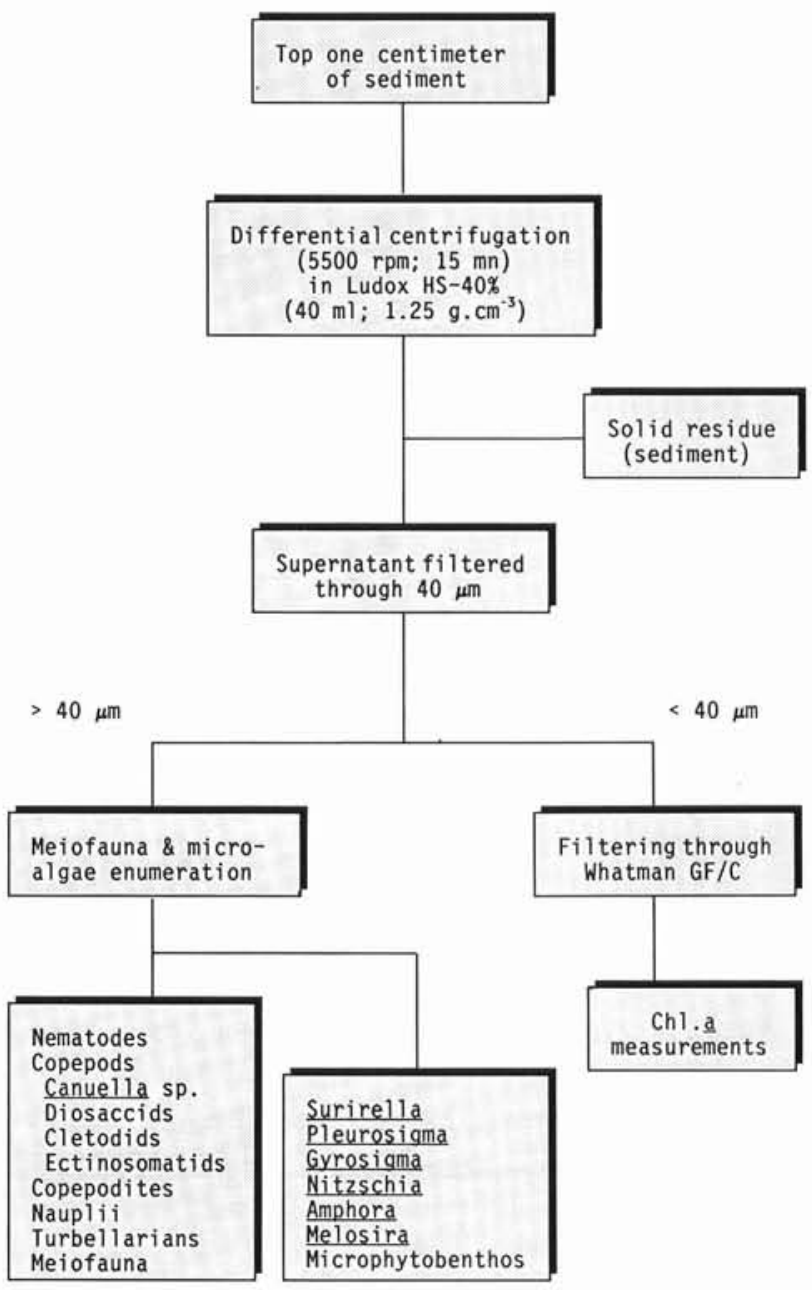

Fig. 2. Protocol of Blanchard et al. (1988), using Ludox HS-40, for simultaneous separation of both meiofauna and microphytobenthos 
Gyrosigma have been pooled in one group. The socalled nanophytobenthos fraction (Riaux \& Germain 1980), suspended in the supernatant Ludox sieved through $40 \mu \mathrm{m}$, was trapped on glass fiber filters (Whatman GF/C) and chlorophyll a concentration was measured spectrophotometrically (Lorenzen 1967).

Microscale dispersion analyses of meiobenthos, diatoms and pigment concentrations were conducted using spatial autocorrelation (Cliff \& Ord 1973, Jumars et al. 1977). This technique establishes a relation between the different values taken by a random variate and its spatial distribution to detect and measure the relative magnitude of aggregations. Moran's and Geary's index (weighing of distance ${ }^{-2}$; Jumars et al. 1977), and Fisher's index $\left(\mathrm{s}^{2} / \overline{\mathrm{x}}\right)$ were used to analyze spatial patterns. Moran's I ranges from -1 (maximum negative autocorrelation) to +1 (maximum positive autocorrelation) with the expected value of no autocorrelation equal to $\mathrm{E}(\mathrm{I})=-(\mathrm{n}-1)-1$; Geary's $\mathrm{c}$ ranges from 0 for maximum positive autocorrelation to a positive value $(>1)$ for negative autocorrelation (the expected value is $\mathrm{E}(\mathrm{c})=1)$. Moran's I detects aggregation due to extreme values in several adjacent cores, whereas Geary's c tests whether adjacent cores contain similar abundances (Jumars et al. 1977).

Patch size was determined using correlograms where I and c were plotted versus inter-sample distance (Jumars 1978, Sokal \& Oden 1978). Inter-sample distances were set as the Euclidian distance between centers of neighboring cores, considering all directions, and ranged from 2 to $14 \mathrm{~cm}$ (maximum distance on the sampling area). As an example, Fig. 3 shows that the patch radius (hence the patch size) is the inter-sample distance corresponding to the crossing of I or c lines with the expected value lines (horizontal lines) (Legendre \& Legendre 1984).

\section{RESULTS}

Densities were significantly different $(\mathrm{p}<0.05)$ over the 2 sampling periods (Table 1 ). Lower values were recorded in May 1987 than in April 1988 for total meiofauna (344.72 \pm 12.01 ind. core $^{-1}$ in 1987 and $197.52 \pm 7.94$ ind. core ${ }^{-1}$ in 1988) and microalgae $\left(1344.40 \pm 67.08\right.$ cells core ${ }^{-1}$ in 1987 and 403.95 \pm 23.74 cells core ${ }^{-1}$ in 1988). The same change occurred for the nanophytobenthos (algal cells $<40 \mu \mathrm{m}$ ), as estimated by chlorophyll a concentration (from $1.17 \pm 0.1$ $\mu \mathrm{g} \mathrm{g}^{-1}$ dry weight sediment to $1.07 \pm 0.06 \mu \mathrm{g} \mathrm{g}^{-1}$ ), but it was not significantly different. Relative abundances in meiofauna taxonomic composition were very similar for the 2 periods (Table 1). Nematodes constituted the dominant taxon $(61.37 \%$ in May 1987 and $77.80 \%$ in April 1988) followed by nauplii (26.60 and $17.18 \%)$,
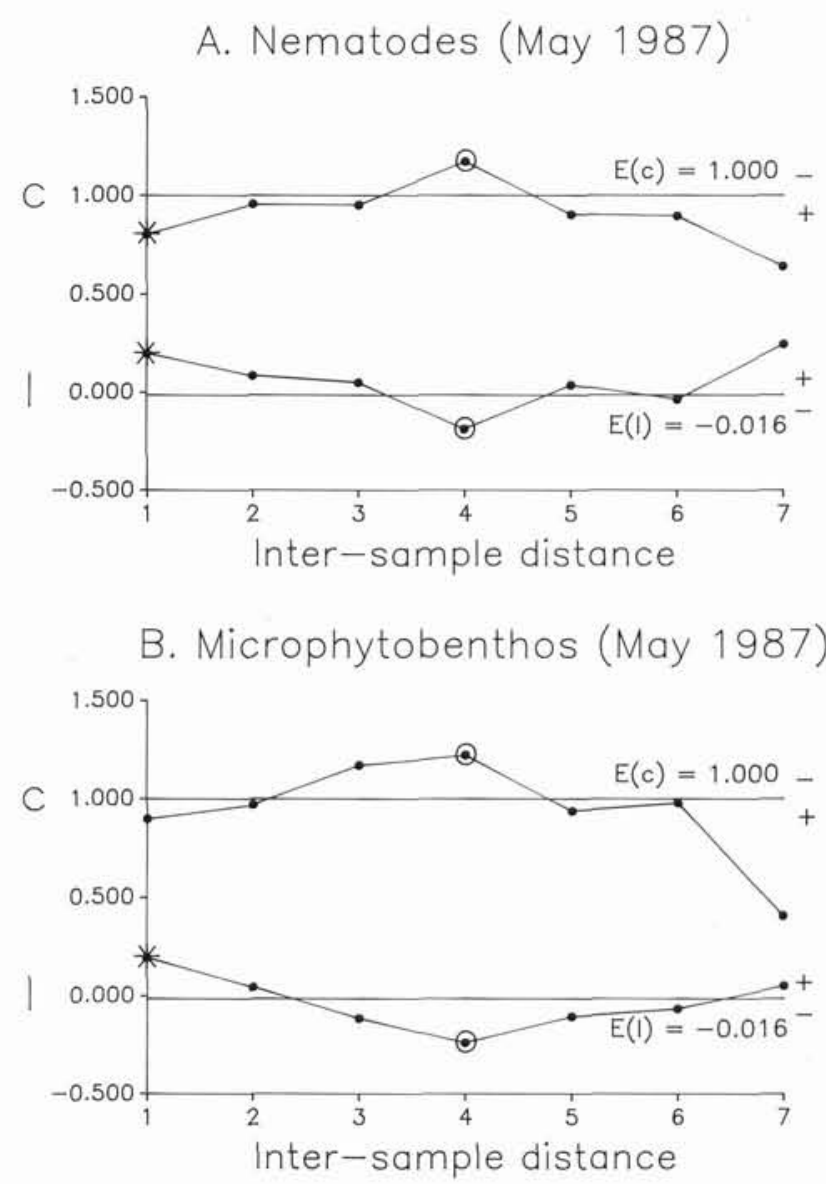

Fig. 3. Correlograms of I and c versus inter-sample distance for (A) nematodes and (B) microphytobenthos in May 1987. Expected values (random dispersion) are indicated by horizontal lines; deviation showing positive autocorrelation is given in the right-hand margin. (*) Significant autocorrelation at the $1 \%$ level; $(0)$ at the $5 \%$ level

adult copepods (9.75 and $3.83 \%$ ), copepodites (1.55 and $1.21 \%)$ and turbellarians $(0.72 \%$ and absent from the second sample). On the other hand, microphytobenthos community structure changed. Abundances of centric diatoms dominated the community $(77.12 \%$ Surirella) in May 1987, but pennate diatoms dominated (89.74 \% Pleurosigma-Gyrosigma) in April 1988.

Most meiofauna and microphytobenthos had a patchy distribution since Fisher's index is significantly greater than 1. However, turbellarians in May 1987, copepodites and harpacticoids (Canuella sp., diosaccids, cletodids, ectinosomatids) in April 1988 were not aggregated (Table 1). The latter fit Poisson distribution, thus describing a random dispersion. Coefficients of variation for chlorophyll $a$ were respectively 65.56 and $43.93 \%$ for the 2 samples, indicating a very high spatial heterogeneity of pigment concentrations as previously observed by Plante-Cuny (1978).

For spatial autocorrelation analysis, Moran's and 
Table 1. Meiofauna and microphytobenthos univariate statistics during 2 sampling periods (core size: $\left.0.64 \mathrm{~cm}^{2}\right)$. $(\%):$ Relative abundance; $(\overline{\mathrm{x}})$ : Mean; SE: Standard Error; $\mathrm{s}^{2}$ : Variance; $\mathrm{s}^{2} \sqrt{\mathrm{x}}$ : Fisher's index. ND: not detected

\begin{tabular}{|c|c|c|c|c|c|c|c|c|}
\hline \multirow{2}{*}{$\begin{array}{l}\text { Taxonomic } \\
\text { group }\end{array}$} & \multicolumn{4}{|c|}{ May 1987} & \multicolumn{4}{|c|}{ April 1988} \\
\hline & $(\%)$ & $\bar{x} \pm S E$ & $\mathrm{~s}^{2}$ & Fisher & $(\%)$ & $\overline{\mathrm{x}} \pm \mathrm{SE}$ & $s^{2}$ & Fisher \\
\hline \multicolumn{9}{|l|}{ Meiofauna } \\
\hline Copepods & 9.75 & $33.62 \pm 2.15$ & 295.95 & $7.61 \cdots$ & 3.83 & $7.32 \pm 0.46$ & 4.48 & $1.97^{\circ}$ \\
\hline Copepodites & 1.55 & $5.35 \pm 0.39$ & 9.59 & $1.81 \cdots$ & 1.21 & $2.32 \pm 0.21$ & 2.84 & $1.22^{\mathrm{NS}}$ \\
\hline Nauplii & 26.60 & $91.71 \pm 4.11$ & 1078.83 & $11.76 \cdots$ & 17.18 & $33.06 \pm 1.63$ & 170.4 & $5.15^{\cdots} \cdots$ \\
\hline \multicolumn{9}{|l|}{ Harpacticoids } \\
\hline Canuella sp. & 13.51 & $4.54 \pm 0.39$ & 9.68 & $2.13^{\cdots}$ & 0.68 & $0.05 \pm 0.03$ & 0.04 & $0.94^{\mathrm{NS}}$ \\
\hline Diosaccids & 25.11 & $8.44 \pm 0.59$ & 22.71 & $2.69 \cdots$ & 25.41 & $1.87 \pm 0.17$ & 1.92 & $1.03^{\mathrm{NS}}$ \\
\hline Cletodids & 32.58 & $10.95 \pm 1.03$ & 68.23 & $6.23 \cdots$ & 43.34 & $3.19 \pm 0.31$ & 6.15 & $1.93^{\mathrm{NS}}$ \\
\hline Ectinosomatids & 28.80 & $9.68 \pm 0.75$ & 35.99 & $3.72 \cdots$ & 30.57 & $2.25 \pm 0.20$ & 2.56 & $1.14^{\mathrm{NS}}$ \\
\hline Nitzschia & 1.13 & $15.29 \pm 1.75$ & 195.00 & $12.75 \cdots$ & 3.71 & $14.97 \pm 2.43$ & 378.75 & $25.30^{\cdots} \cdots$ \\
\hline Amphora & 10.33 & $138.92 \pm 8.88$ & 5050.00 & $36.35 \cdots$ & 2.27 & $9.17 \pm 1.47$ & 139.20 & $15.17^{\cdots} \cdots$ \\
\hline Melosira & 2.78 & $37.44 \pm 7.24$ & 3360.00 & $89.74 \cdots$ & 2.02 & $8.17 \pm 2.62$ & 437.86 & $53.56^{\cdots} \cdots$ \\
\hline Pennate diatoms & 18.09 & $242.94 \pm 16.01$ & 16400.00 & $67.51 \cdots$ & 95.72 & $386.65 \pm 23.16$ & 34323.47 & $88.77^{\cdots}$ \\
\hline Microphytobenthos & 100.00 & $1344.40 \pm 67.08$ & 288000.00 & $214.22 \cdots$ & 100.00 & $403.95 \pm 23.74$ & 36085.95 & $89.33^{\cdots} \cdot$ \\
\hline
\end{tabular}

Geary's index were calculated versus inter-sample distances. Correlograms (Fig. 3 is an example) were used to derive patch size. When Fisher's index is significant but I and c are not, it means that the size of the aggregates is less than sampling scale (Sokal \& Wartenberg 1981). Therefore, patch size is less than $4 \mathrm{~cm}^{2}$. This was true for total adult copepods, Canuella sp., and cletodids (Table 2); the microalgae Melosira and chlorophyll a concentration (Table 3) in May 1987; nematodes, total adult copepods, total meiofauna (Table 4); and the genera Nitzschia and Melosira (Table 5) in April 1988. If Moran's index is significant but Geary's is not, then aggregation is due to few patches of extreme abundances. This is true for the copepods and diosaccids (Table 2) and the microalgae Surirella and total microphytobenthos (Table 3) in May 1987. The harpacticoid ectinosomatids in May 1987 (Table 2) were distributed in many patches of the same abundance since $\mathrm{c}$ is significant but I is not. All other groups had 3 significant dispersion indexes, indicating a high tendency to aggregate. Some harpacticoids (total adults, copepodite stage, cletodids and ectinosomatids [Table 2] in May 1987 and nauplii stage [Table 4] in April 1988) exhibited patches themselves aggregated into larger clumps (clump is defined hereafter as the aggregation of primary patches). Patches and clumps constitute what is known as 2-level patchiness. The corresponding correlograms indicated clumps larger than the sampling area. This was not detected with either other meiofauna taxa or microphytobenthos and nanophytobenthos. Considering all meiofauna taxa and microphyte genera, patch size was very variable between years (Table 6).

To detect spatial overlaps, a log-log regression was performed between all possible meiofauna-microalgae densities. Only significant associations from 152 regressions are reported in Table 7 . Total meiofauna always exhibit a spatial coupling with total microphytobenthos (correlation coefficients were respectively significant for $\mathrm{p}<0.01$ and $\mathrm{p}<0.05)$. Nematodes were positively associated with Pleurosigma-Gyrosigma over the 2 sampling periods $(\mathrm{p}<0.05)$ and with Surirella in May $1987(\mathrm{p}<0.001)$ whereas cletodids $(\mathrm{p}<0.01)$, ectinosomatids $(\mathrm{p}<0.001)$, copepodites $(\mathrm{p}<0.01)$ and nauplii $(\mathrm{p}<0.01)$ showed significant associations with the microalgae Amphora in May 1987. Unexpectedly, the harpacticoid cletodids and the nauplii were negatively associated with the alga Amphora $(\mathrm{p}<0.05)$ in April 1988. Total adult copepods and the harpacticoid Canuella sp. were never involved in a significant correlation with any microphyte genera. Chlorophyll a concentrations only showed negative associations with total adult copepods and copepodites $(\mathrm{p}<0.05)$ in May 1987. 
Table 2. Statistics for meiofauna spatial autocorrelation analysis in May 1987. I: Moran's index; c: Geary's index as a function of inter-sample distance for meiofauna taxa. (Expected values $\mathrm{E}(\mathrm{I})=-0.016$ and $\mathrm{E}(\mathrm{c})=1.000$ )

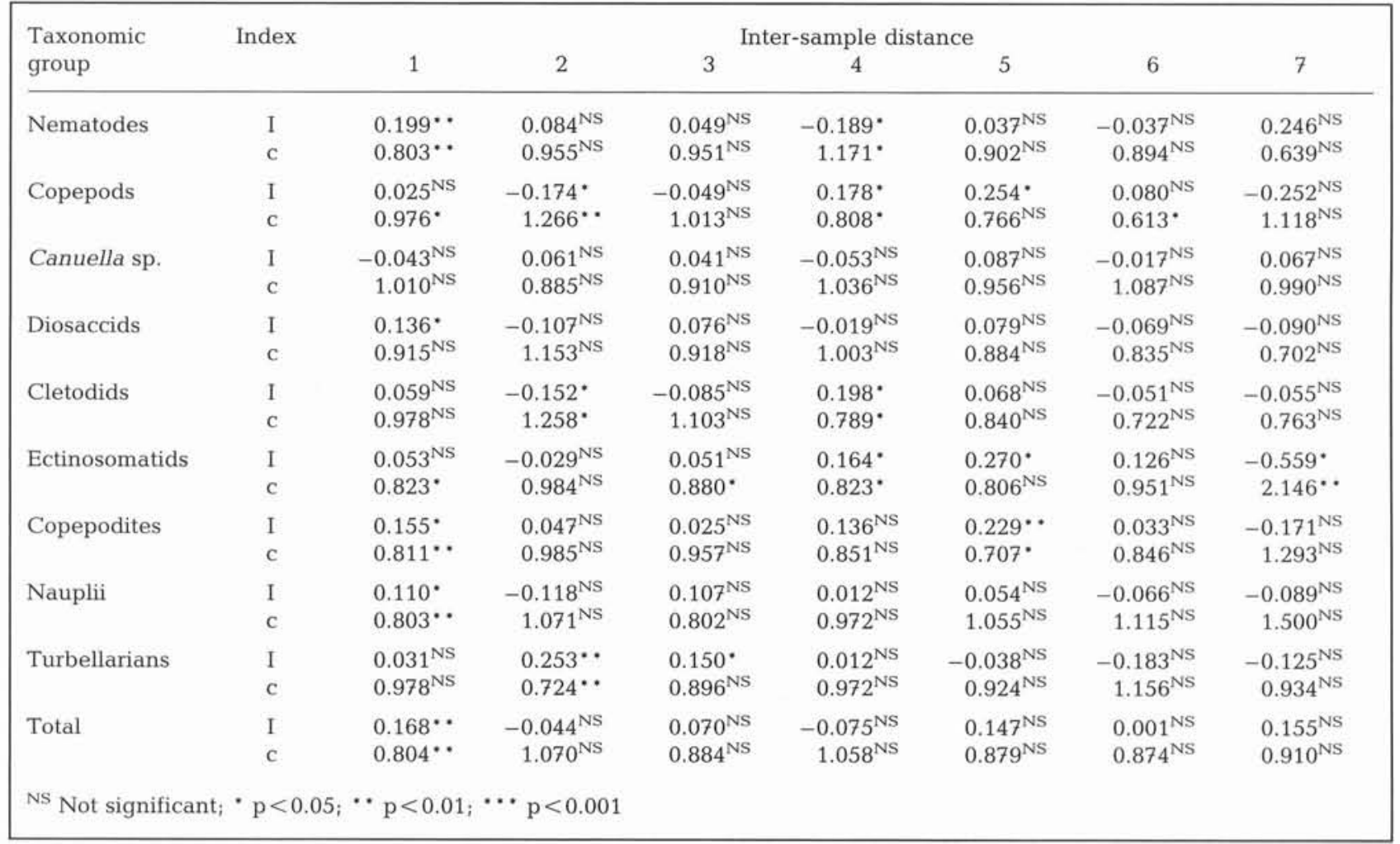

Table 3. Statistics for microphytobenthos spatial autocorrelation analysis in May 1987. I: Moran's index; c: Geary's index as a function of inter-sample distance for microalgae taxa. (Expected values $E(I)=-0.016$ and $E(c)=1.000)$

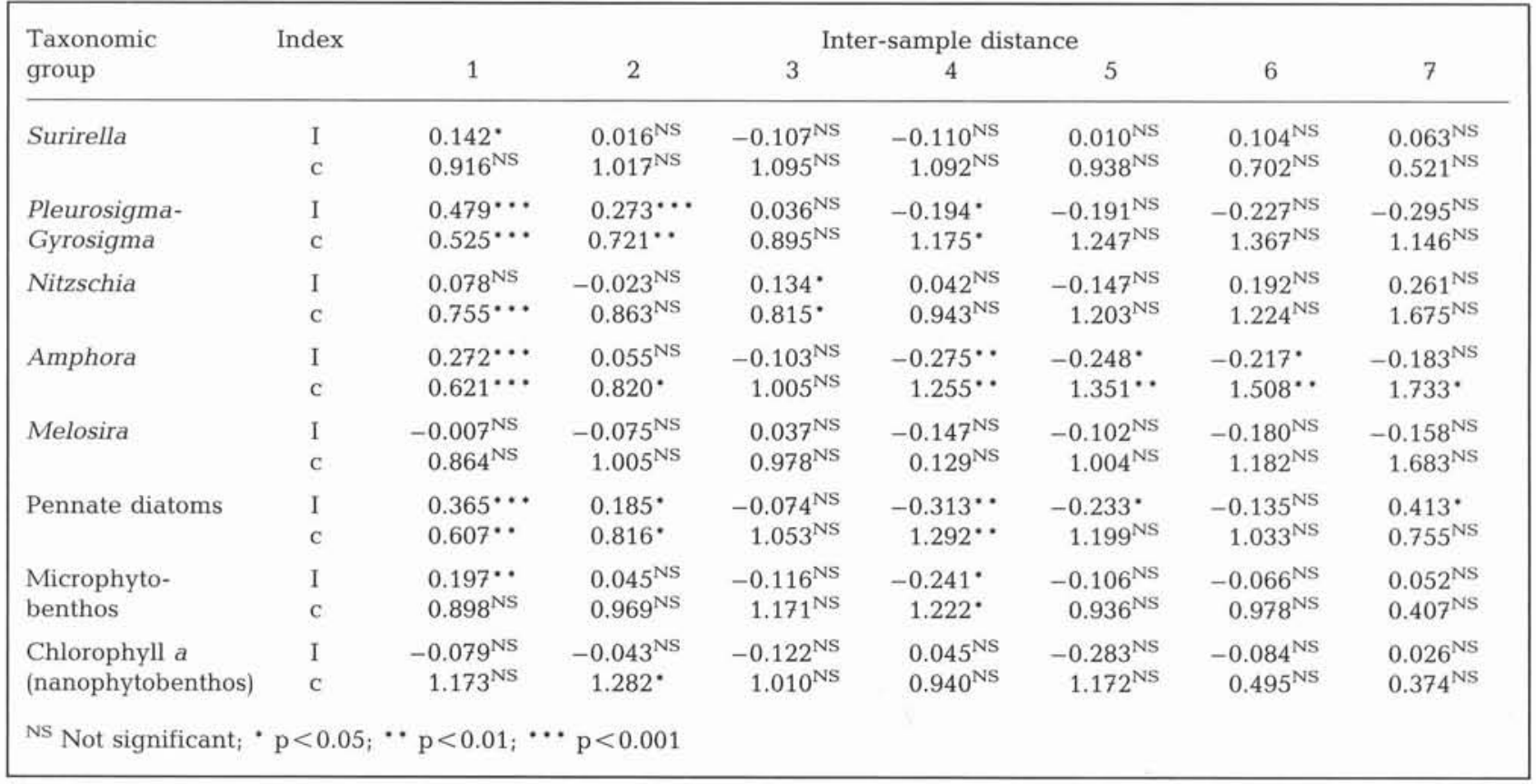


Table 4. Statistics for meiofauna spatial autocorrelation analysis in April 1988. I: Moran's index; c: Geary's index as a function of inter-sample distance for meiofauna taxa in April 1988. (Expected values $E(I)=-0.016$ and $E(c)=1.000$ )

\begin{tabular}{|c|c|c|c|c|c|c|c|c|}
\hline \multirow{2}{*}{$\begin{array}{l}\text { Taxonomic } \\
\text { groups }\end{array}$} & \multirow[t]{2}{*}{ Index } & \multicolumn{7}{|c|}{ Inter-sample distance } \\
\hline & & 1 & 2 & 3 & 4 & 5 & 6 & 7 \\
\hline Nematodes & $\begin{array}{l}\text { I } \\
\text { c }\end{array}$ & $\begin{array}{r}-0.083^{\mathrm{NS}} \\
1.052^{\mathrm{NS}}\end{array}$ & $\begin{array}{l}0.082^{\mathrm{NS}} \\
0.913^{\mathrm{NS}}\end{array}$ & $\begin{array}{l}0.008^{\mathrm{NS}} \\
1.072^{\mathrm{NS}}\end{array}$ & $\begin{array}{l}-0.048^{\circ} \\
1.032^{\mathrm{NS}}\end{array}$ & $\begin{array}{l}0.028^{\mathrm{NS}} \\
0.799^{\mathrm{NS}}\end{array}$ & $\begin{array}{l}0.017^{\mathrm{NS}} \\
0.904^{\mathrm{NS}}\end{array}$ & $\begin{array}{l}0.110^{\mathrm{NS}} \\
0.970^{\mathrm{NS}}\end{array}$ \\
\hline Copepods & $\begin{array}{l}\mathrm{I} \\
\mathrm{C}\end{array}$ & $\begin{array}{r}-0.043^{\mathrm{NS}} \\
0.973^{\mathrm{NS}}\end{array}$ & $\begin{array}{r}-0.114^{\mathrm{NS}} \\
1.084^{\mathrm{NS}}\end{array}$ & $\begin{array}{l}0.094^{\mathrm{NS}} \\
0.876^{\mathrm{NS}}\end{array}$ & $\begin{array}{l}0.069^{*} \\
0.917^{\mathrm{NS}}\end{array}$ & $\begin{array}{r}-0.192^{\mathrm{NS}} \\
1.194^{\mathrm{NS}}\end{array}$ & $\begin{array}{l}0.062^{\mathrm{NS}} \\
1.002^{\mathrm{NS}}\end{array}$ & $\begin{array}{c}-0.215^{\mathrm{NS}} \\
1.547^{\circ}\end{array}$ \\
\hline Canuella sp. & $\begin{array}{l}\mathrm{I} \\
\mathrm{C}\end{array}$ & $\begin{array}{r}-0.029^{\mathrm{NS}} \\
0.821^{\mathrm{NS}}\end{array}$ & $\begin{array}{r}-0.034^{\mathrm{NS}} \\
0.876^{\mathrm{NS}}\end{array}$ & $\begin{array}{l}0.051^{\mathrm{NS}} \\
0.997^{\mathrm{NS}}\end{array}$ & $\begin{array}{r}-0.049^{\mathrm{NS}} \\
1.033^{\mathrm{NS}}\end{array}$ & $\begin{array}{r}-0.034^{\mathrm{NS}} \\
0.870^{\mathrm{NS}}\end{array}$ & $\begin{array}{r}-0.082^{\mathrm{NS}} \\
1.377^{\mathrm{NS}}\end{array}$ & $\begin{array}{r}-0.136^{\mathrm{NS}} \\
1.944^{\mathrm{NS}}\end{array}$ \\
\hline Diosaccids & $\begin{array}{l}\mathrm{I} \\
\mathrm{C}\end{array}$ & $\begin{array}{r}-0.007^{\mathrm{NS}} \\
0.979^{\mathrm{NS}}\end{array}$ & $\begin{array}{r}-0.030^{\mathrm{NS}} \\
1.058^{\mathrm{NS}}\end{array}$ & $\begin{array}{l}0.222^{\circ} \\
0.796^{*}\end{array}$ & $\begin{array}{l}0.016^{\mathrm{NS}} \\
0.969^{\mathrm{NS}}\end{array}$ & $\begin{array}{r}-0.191^{\mathrm{NS}} \\
1.101^{\mathrm{NS}}\end{array}$ & $\begin{array}{r}-0.128^{\mathrm{NS}} \\
1.050^{\mathrm{NS}}\end{array}$ & $\begin{array}{c}-0.472^{\mathrm{NS}} \\
1.527^{\circ}\end{array}$ \\
\hline Cletodids & $\begin{array}{l}\mathrm{I} \\
\mathrm{C}\end{array}$ & $\begin{array}{l}0.005^{\mathrm{NS}} \\
0.948^{\mathrm{NS}}\end{array}$ & $\begin{array}{r}-0.158^{\circ} \\
1.156^{\circ}\end{array}$ & $\begin{array}{l}0.188^{\circ} \\
0.803^{\circ}\end{array}$ & $\begin{array}{l}0.050^{\mathrm{NS}} \\
0.935^{\mathrm{NS}}\end{array}$ & $\begin{array}{r}-0.147^{\mathrm{NS}} \\
1.104^{\mathrm{NS}}\end{array}$ & $\begin{array}{r}-0.058^{\mathrm{NS}} \\
0.983^{\mathrm{NS}}\end{array}$ & $\begin{array}{r}-0.156^{\mathrm{NS}} \\
1.358^{\mathrm{NS}}\end{array}$ \\
\hline Ectinosomatids & $\begin{array}{l}\text { I } \\
\text { c }\end{array}$ & $\begin{array}{r}-0.025^{\mathrm{NS}} \\
1.069^{\mathrm{NS}}\end{array}$ & $\begin{array}{r}-0.056^{\mathrm{NS}} \\
1.008^{\mathrm{NS}}\end{array}$ & $\begin{array}{r}-0.143^{\mathrm{NS}} \\
1.137^{\mathrm{NS}}\end{array}$ & $\begin{array}{r}-0.107^{\mathrm{NS}} \\
1.090^{\mathrm{NS}}\end{array}$ & $\begin{array}{r}-0.088^{\mathrm{NS}} \\
1.036^{\mathrm{NS}}\end{array}$ & $\begin{array}{l}0.016^{\mathrm{NS}} \\
1.045^{\mathrm{NS}}\end{array}$ & $\begin{array}{r}-0.042^{\mathrm{NS}} \\
0.683^{\mathrm{NS}}\end{array}$ \\
\hline Copepodites & $\begin{array}{l}\text { I } \\
\text { c }\end{array}$ & $\begin{array}{l}0.003^{\mathrm{NS}} \\
0.908^{\mathrm{NS}}\end{array}$ & $\begin{array}{r}-0.041^{\mathrm{NS}} \\
0.940^{\mathrm{NS}}\end{array}$ & $\begin{array}{l}0.152^{\circ} \\
0.810^{\circ}\end{array}$ & $\begin{array}{l}0.021^{\mathrm{NS}} \\
0.964^{\mathrm{NS}}\end{array}$ & $\begin{array}{l}0.097^{\mathrm{NS}} \\
0.946^{\mathrm{NS}}\end{array}$ & $\begin{array}{r}-0.386^{*} \\
1.632 \%\end{array}$ & $\begin{array}{r}-0.250^{\mathrm{NS}} \\
1.702^{\circ}\end{array}$ \\
\hline Nauplii & $\begin{array}{l}\text { I } \\
\text { c }\end{array}$ & $\begin{array}{r}-0.049^{\mathrm{NS}} \\
0.988^{\mathrm{NS}}\end{array}$ & $\begin{array}{l}0.199^{*} \\
0.818^{*}\end{array}$ & $\begin{array}{r}-0.035^{\mathrm{NS}} \\
1.058^{\mathrm{NS}}\end{array}$ & $\begin{array}{l}0.186^{*} \\
0.801^{\circ}\end{array}$ & $\begin{array}{r}-0.006^{\mathrm{NS}} \\
0.940^{\mathrm{NS}}\end{array}$ & $\begin{array}{r}-0.227^{\mathrm{NS}} \\
1.136^{\mathrm{NS}}\end{array}$ & $\begin{array}{l}0.054^{\mathrm{NS}} \\
1.156^{\mathrm{NS}}\end{array}$ \\
\hline Total & $\begin{array}{l}\mathrm{I} \\
\mathrm{C}\end{array}$ & $\begin{array}{r}-0.115^{\mathrm{NS}} \\
1.076^{\mathrm{NS}}\end{array}$ & $\begin{array}{l}0.074^{\mathrm{NS}} \\
0.932^{\mathrm{NS}}\end{array}$ & $\begin{array}{l}0.025^{\mathrm{NS}} \\
1.043^{\mathrm{NS}}\end{array}$ & $\begin{array}{l}0.004^{\mathrm{NS}} \\
0.980^{\mathrm{NS}}\end{array}$ & $\begin{array}{r}-0.006^{\mathrm{NS}} \\
0.859^{\mathrm{NS}}\end{array}$ & $\begin{array}{r}-0.069^{\mathrm{NS}} \\
0.970^{\mathrm{NS}}\end{array}$ & $\begin{array}{l}0.155^{\mathrm{NS}} \\
0.967^{\mathrm{NS}}\end{array}$ \\
\hline
\end{tabular}

Table 5. Statistics for microphytobenthos spatial autocorrelation analysis in April 1988. I: Moran's index; c: Geary's index as a function of inter-sample distance for microalgae in April 1988. (Expected values $E(I)=-0.016$ and $E(c)=1.000$ )

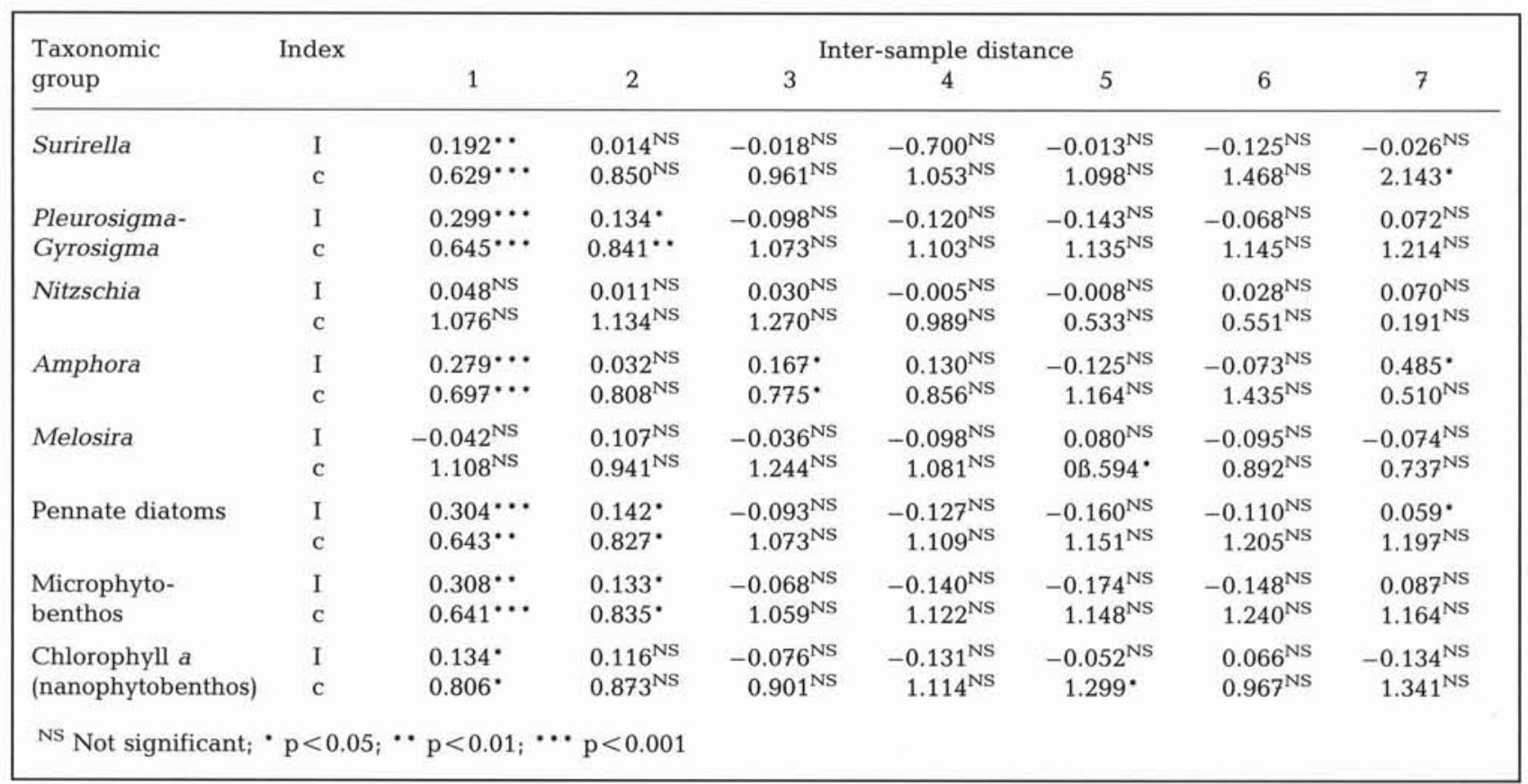


Table 6. Mean patch size $\left(\mathrm{cm}^{2}\right)$ for meiofauna and microalgal cells in May 1987 and April 1988. Patches refer to first aggregation level and clumps to second clumping level each time it occurred or not $(+/-)$

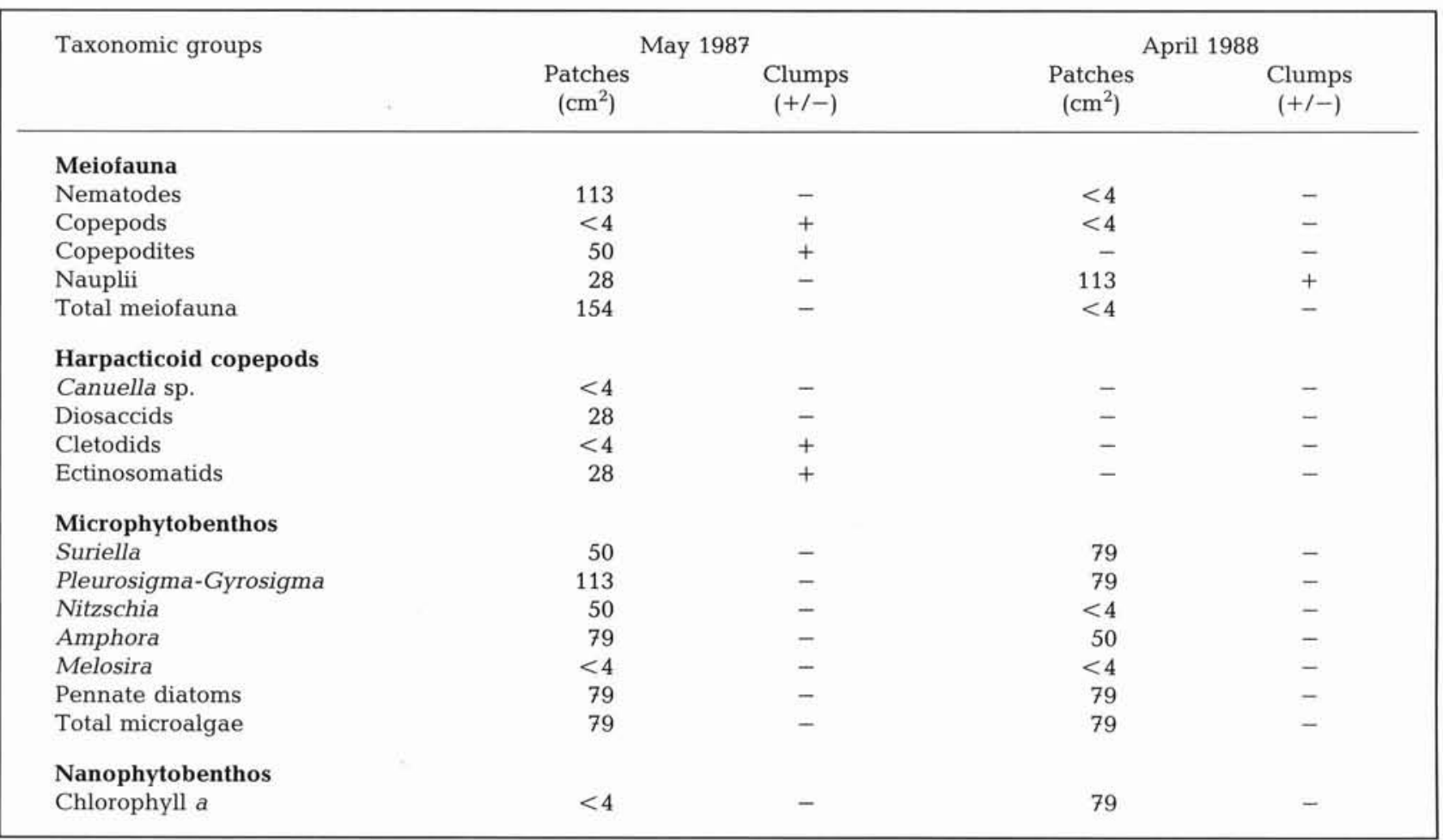

Table 7. Significant spatial associations between meiofauna taxa and microphytobenthos assemblages at the 2 sampling periods. $\mathrm{r}$ : Pearson product moment correlation coefficient; $\mathrm{n}=64$

\begin{tabular}{|c|c|c|c|}
\hline Periods & Meiofauna & Microphytobenthos & $\mathrm{r}$ \\
\hline \multirow[t]{7}{*}{ May 1987} & Nematodes & $\begin{array}{l}\text { Surirella } \\
\text { Pleurosigma-Gyrosigma } \\
\text { Total microalgae }\end{array}$ & $\begin{array}{l}0.437^{*} \cdots \\
0.258^{*} \\
0.439^{*} \cdots\end{array}$ \\
\hline & Diosaccids & $\begin{array}{l}\text { Pleurosigma-Gyrosigma } \\
\text { Pennate diatoms }\end{array}$ & $\begin{array}{l}0.262^{\circ} \\
0.249^{\circ}\end{array}$ \\
\hline & Cletodids & Amphora & $0.342^{\cdots}$ \\
\hline & Ectinosomatids & $\begin{array}{l}\text { Amphora } \\
\text { Nitzschia }\end{array}$ & $\begin{array}{l}0.451^{\cdots} \cdots \\
0.335^{\cdots}\end{array}$ \\
\hline & Copepodites & Amphora & $0.400^{\cdots}$ \\
\hline & Nauplii & Amphora & $0.344^{\cdots}$ \\
\hline & Total meiofauna & $\begin{array}{l}\text { Surirella } \\
\text { Amphora } \\
\text { Total microalgae }\end{array}$ & $\begin{array}{l}0.376^{*} \\
0.265^{*} \\
0.368^{*}\end{array}$ \\
\hline \multirow[t]{4}{*}{ April 1988} & Nematodes & $\begin{array}{l}\text { Pleurosigma-Gyrosigma } \\
\text { Nitzschia } \\
\text { Pennate diatoms } \\
\text { Total microalgae }\end{array}$ & $\begin{array}{l}0.240^{\circ} \\
0.241^{\circ} \\
0.268^{\circ} \\
0.261^{\circ}\end{array}$ \\
\hline & Cletodids & Amphora & $-0.250^{\circ}$ \\
\hline & Nauplii & Amphora & $-0.294^{\circ}$ \\
\hline & Total meiofauna & $\begin{array}{l}\text { Pennate diatoms } \\
\text { Total microalgae }\end{array}$ & $\begin{array}{l}0.249^{*} \\
0.241^{*}\end{array}$ \\
\hline
\end{tabular}




\section{DISCUSSION}

When the aim of a sampling is to examine biological interactions among communities via interpretation of distribution patterns, sampling scale is important. An inappropriate sampling scale may mask spatial heterogeneity and lead to erroneous conclusions. Findlay (1982) showed that a large number of small cores ( 50 cores of 0.5 to $1.0 \mathrm{~cm}^{2}$ ) gives the best resolution for meiofauna patterns, since a larger sampling scale failed to detect contagious distributions. The design in the present study (64 cores of $0.64 \mathrm{~cm}^{2}$ covering $256 \mathrm{~cm}^{2}$ ) offers the most information for the least effort. Extrapolating the surface area of the core to the larger quadrat area $\left(4 \mathrm{~cm}^{2}\right)$ would still allow realistic interpretations. Meiofauna patchiness is very likely to be variable (Findlay 1981), therefore a large number of cores delimiting a relatively large area is preferable to duplicates or even triplicates which, for the same sampling effort, would be made by fewer cores and would cover smaller areas. As a result, these replicates may fail to detect largest structures such as clumps (characteristic of a 2-level patchiness).

Results in the present study are consistent with the hypothesis of a meiofaunal response to microphytobenthos patchiness since both meiofauna and microalgae exhibited a patchy distribution and a significant spatial coupling did exist. Although meiobenthos aggregation has well been documented (see Fleeger \& Decho 1987 for a review), few investigations have been conducted to determine patch size. The present work provides estimations that lie within the range reported in Table 6 $\left(<4\right.$ to $\left.154 \mathrm{~cm}^{2}\right)$. Findlay (1981) found lower values in a muddy sediment $\left(0.3\right.$ to $\left.24 \mathrm{~cm}^{2}\right)$ but Heip \& Engels (1977) reported considerable larger patches in a sandy sediment $\left(80\right.$ to $\left.700 \mathrm{~cm}^{2}\right)$. Findlay (1981) also detected a second aggregation level with harpacticoid copepods ranging from 5 to $32 \mathrm{~cm}^{2}$ depending on species whereas this study suggests values higher than the sampling area with higher densities. A reproductive behavior might result in 2 levels of patchiness (Findlay 1981). In May 1987, nauplii were patchy at $28 \mathrm{~cm}^{2}$ while copepodites and total adults showed aggregation at 50 and $4 \mathrm{~cm}^{2}$, respectively. Smaller patches of adults may have been made up of reproductively active individuals (therefore the $28 \mathrm{~cm}^{2}$ patches of nauplii), while the larger clumps were non-reproductive. On the other hand, this explanation is not consistent with the 1988 sample (Table 6), since nauplii exhibited a 2-level heterogeneity but adults did not. Other factors not investigated in this study, such as bacteria-meiofauna interrelationships, might influence meiofauna patch size (Gray \& Johnson 1970, Rieper 1978).

Microphytobenthos microscale spatial pattern has had fewer investigations. Although aggregation has previously been mentioned (Plante-Cuny 1978, Decho \& Fleeger 1988) and has been related to sedimentary structures (Plante et al. 1986) or nutrient efflux (Höpner \& Wonneberger 1985), no data exist concerning patch size and its taxonomic composition. In this study, at the 2 sampling periods, microalgae patches (cells $>40 \mu \mathrm{m}$ ) ranged from less than $4 \mathrm{~cm}^{2}$ to $113 \mathrm{~cm}^{2}$, close to the magnitude of meiofauna first aggregation level. On the other hand, nanophytobenthos (cells $<40 \mu \mathrm{m}$ ) exhibited aggregates of $79 \mathrm{~cm}^{2}$ or less than $4 \mathrm{~cm}^{2}$, revealing a discrepancy with meiofauna clumping and suggesting that the sampling scale was suitable for both meiofauna and microphytobenthos but not for small algal cells. This may explain the lack of positive association between meiofauna and nanophytobenthos. Therefore, a correlation appears to exist between algal cells and their patch size. Bell \& Mitchell (1972) and Bell et al. (1974) have previously noted that microbe patches could be very small compared to meiofauna. A further hypothesis is that bacteria, which are even smaller than nanophytobenthos, would not be correlated with meiofauna. This was shown by Montagna et al. (1983) who also observed a positive correlation with sediment diatoms. However, Gray (1966a, 1967a, b, 1968) and Gray \& Johnson (1970) showed that bacteria infuenced meiofauna patch formation.

Correlation coefficients show significant relationships between total meiofauna and total microphytobenthos (large cells), as well as between groups of higher taxonomic levels. Changes in taxonomic associations occurred between years and were related to alterations in relative abundances. Because of this change, nematodes were positively associated with the dominant microalgae genera, namely Surirella (69\% of microphytes community in May 1987) and Pleurosigma-Gyrosigma (90\% in April 1988). They were also associated with the Pleurosigma-Gyrosigma group in May 1987 when it constituted only $8 \%$ of the community, indicating specificity of this spatial association. The microalgae Amphora (9\% in May 1987) appeared to be selectively attractive for most harpacticoids (Cletodidae, Ectinosomatidae, copepodites and nauplii stages). These associations were not detected in April 1988 probably because the decrease in Amphora density made the abundances of the harpacticoids very low. Austen (1989) experimentally observed a similar effect and pointed out that harpacticoid copepods were more affected than nematodes by a feeding regime change because they appeared to be less flexible in their nutritional requirements. In showing that 2 or more diatom genera may be needed to satisfy the nutritional requirements of meiobenthos, especially nematodes, the present study confirms Austen's hypothesis. Nutritional value of algal diet influences growth and reproduction rates of nematodes (Lee \& 
Lee 1979, Jensen 1984) and harpacticoid copepods (Nilsson 1987). The physiological (digestive enzymes) and morphological (mouthparts) abilities of nematodes and copepods explain discrimination between cells (Tietjen \& Lee 1973, 1977, Vanden Berghe \& Bergmans 1981, Jensen 1987). So meiobenthos microscale dispersion may very likely mirror its selective ingestion and assimilation. Further, Warwick et al. (1984) showed that macrofauna predation and disturbance activities could induce either microalgae-feeding or bacteriafeeding meiofaunal communities, also explaining, to a certain extent, microphytobenthos-meiofauna interaction variability.

Interpretation of negative correlations detected in April 1988 (Table 7) is uncertain. These meiofauna taxa and microalgae could exhibit spatial avoidance but this explanation is contradictory since some of these pairs were involved in positive associations in May 1987 (cletodids-Amphora, nauplii-Amphora). The alternative is that negative associations resulted from active consumption by meiofauna, clumps of which might be temporarily displaced from the corresponding microbial clumps.

Although meiofauna taxa and microalgae genera involved in significant associations exhibited patches of the same magnitude, no very close overlaps occurred among their spatial patterns. For instance, total meiofauna sampled in May 1987 was distributed in patches of $154 \mathrm{~cm}^{2}$ co-occuring with microphytobenthos clumps of $79 \mathrm{~cm}^{2}$. The situation was completely different in April 1988 since meiofauna patches (less than $4 \mathrm{~cm}^{2}$ ) were much smaller than diatom ones $\left(79 \mathrm{~cm}^{2}\right)$. Reported values in Tables 6 and 7 show a similar trend in other associated groups. First, these results stress the presence of a high temporal variability in clump size, as has previously been mentioned for meiofauna (Hogue 1978, Findlay 1981), and second they suggest that diatoms are not the only meiofauna patchiness determinant. An analogous observation was noted by Montagna et al. (1983) during an in situ 1 yr survey. Despite a significant correlation they did not detect a time-lag relationship between meiofauna and diatom abundance peaks that would be expected if meiofauna density was a response to diatom peaks. They stressed that a correlation coefficient does not guarantee, a priori, cause and effect because it is very difficult to consider all possible variables. Hence meiofauna clumping might potentially be a multi-factor response. Such physical and chemical parameters as light, pore water content, grain-size, temperature, oxygen concentration and salinity could play an important role (Gray 1966b, Jansson 1966, 1967, 1968). In the present work, although sampling was performed in the same pond outside water inflow and outflow periods, disruption of spatial patterns by resuspension of sedi- ment must also be taken into account because of wind stress in the $40 \mathrm{~cm}$ shallow water. Besides, several other food resources may influence microscale dispersion of meiofauna in different ways. Bacteria has long been recognized as a nutritional source for meiofauna (Gray 1966a, Gray \& Johnon 1970), particularly for harpacticoid copepods (Gray 1968, Rieper 1978, Carman \& Thistle 1985) and nematodes (Schiemer et al. 1980, Schiemer 1982), and in situ heterotrophic carbon transfer to meiofauna has been measured by Montagna \& Bauer (1988). Ciliates are also grazed by harpacticoids (Rieper \& Flotow 1981) while decaying organisms have been considered a possible cause for nematode aggregation (Gerlach 1977) and phytal detritus might be an important food resource for meiofauna (Couch 1989). Further, complexity among microbes interactions makes the in situ trophic determinism of meiofauna patchiness even more difficult to clarify. In laboratory experiments, Decho \& Castenholz (1986) demonstrated that 2 copepod species fed either only on diatoms or only on bacteria, whereas a third species ingested diatoms but only assimilated bacteria closely associated with frustules and then rejected intact diatoms in fecal pellets. So diatoms might only be an indirect cause in attracting meiofauna, as a simple carrier, as well as the main factor involved in microbemeiofauna relationships, since Montagna (1984) showed that autotrophic carbon flux to nematodes and copepods was higher than heterotrophic carbon transfer. Further, grazing experiments in this oyster pond (Blanchard unpubl.) also appear to confirm the importance of photoautotrophic carbon in meiofauna nutrition.

In conclusion, the data in the present study are consistent with the hypothesis that diatom dispersion partially influences meiofaunal patchiness. Feeding preference is likely the main mechanism responsible for the observed specific assemblages. Complexity of meiofauna-microbe interrelationships (multiple interacting trophic factors) may explain the year-to-year variability and the abscence of close associations between the 2 studied trophic webs. A further hypothesis is that meiofauna and microphytobenthos share similar spatial resource axes (light for photoautotrophs and oxygen concentration for metazoa, both at the very surface of the sediment) and that this relationship is based on the microbial size spectrum, since spatial interactions do not seem to exist between meiofauna and nanophytobenthos. Emphasis has been given to spatial variability rather than temporal fluctuations, and all meiofauna taxa and microphytobenthic genera have been considered so that the temporal dimension could not realistically be integrated in the sampling design. However, future investigations might focus on single species rather than higher taxa since 
most recent findings tend to show selective feeding behavior at the species level. By considering only few species, the counting effort is lowered so that seasonal effects could be integrated in the analysis of meiofauna-microphytobenthos spatial relationships.

Acknowledgements. This paper was extracted from a dissertation submitted for the Ph. D. at the University of Bordeaux I, France. I thank Dr A. Dinet for his helpful participation during the preparation and realization of this study and for his comments on the manuscript. Thanks are due to the Centre de Recherche en Ecologie Marine et Aquaculture de L'Houmeau, France, which provided use of equipment and facilities during this study. I am grateful to Dr P. Montagna for his helpful suggestions during the preparation of this paper and for providing me with the facilities to write this paper at the University of Texas Marine Science Institute, Texas, USA.

\section{LITERATURE CITED}

Austen, M. C. (1989). Factors affecting estuarine meiobenthic assemblage structure: a multifactorial microcosm experiment. J. exp. mar. Biol. Ecol. 130: 167-187

Bell, W. H., Mitchell, R. (1972). Chemotactic and growth responses of marine bacteria to algal extracellular products. Biol. Bull. mar. biol. Lab., Woods Hole 143: 265-277

Bell, S. S., Watzin, M. C., Coull, B. C. (1978). Biogenic structures and its effects on the spatial heterogeneity of meiofauna in a salt marsh. J. exp. mar. Biol. Ecol., 35: 99-107

Bell, W. H., Lang, J. H., Mitchell, R. (1974). Selective stimulation of marine bacteria by algal extracellular products. Limnol. Oceanogr. 19: 833-839

Bernstein, B. B., Hessler, R. R., Smith, R., Jumars, P. (1978). Spatial dispersion of benthic Foraminifera in the abyssal central North Pacific. Limnol. Oceanogr. 23: 401-416

Blanchard, G., Chretiennot-Dinet, M.-J., Dinet, A., Robert, J.M. (1988). Methode simplifiee pour l'extraction du microphytobenthos des sediments marins par le gel de silice Ludox. C. r. Acad. Sci. Paris, Serie III, 307: 569-576

Carman, K. R., Thistle, D. (1985). Microbial food partitioning by three species of benthic copepods. Mar. Biol. 88: 143-148

Chandler, G. T., Fleeger, J. W. (1987). Facilitative and inhibitory interactions among estuarine meiobenthic harpacticoid copepods. Ecology 68 (6): 1906-1919

Cliff, A. D., Ord, J. K. (1973). Spatial autocorrelation. Pion Press, London

Couch, C. A. (1989). Carbon and nitrogen stable isotopes of meiobenthos and their food resources. Estuar. coast. Shelf Sci. 28: 433-441

Coull, B. C., Bell, S. S. (1979). Perspective in marine meiofaunal ecology. In: Livingston, R. J. (ed.) Ecological processes in coastal and marine systems. Plenum Press, New York, p. 189-216

Decho, A. W., Fleeger, J. W. (1988). Microscale dispersion of meiobenthic copepods in response to food-resource patchiness. J. expl. mar. Biol. Ecol. 118: 229-243

Decho, A. W., Hummon, W. D., Fleeger, J. W. (1985). Meiofauna-sediment interactions around subtropical seagrass sediments using factor analysis. J. mar. Res. 43 (1): 237-255

Decho, A. D., Castenholz, R. (1986). Spatial patterns and feeding of meiobenthic harpacticoid copepods in relation to resident microbial flora. Hydrobiologia 131: 87-96

Findlay, S. E. G. (1981). Small-scale spatial distribution of meiofauna on a mud and sandflat. Estuar. coast. Shelf Sci. 12: $471-484$

Findlay, S. E. G. (1982). Influence of sampling scale on apparent distribution of meiofauna on a sandflat. Estuaries 5 (4): $322-324$

Fleeger, J. W., Decho, A. W. (1987). Spatial variability of interstitial meiofauna: a review. Stygologia 3: 35-54

Gerlach, S. A. (1977). Attraction to decaying organisms as a possible cause for distribution of nematodes in a Bermuda beach. Ophelia 16: 151-166

Gray, J. S. (1966a). The attractive factor of intertidal sands to Protodrilus symbioticus. J. mar. biol. Ass. U.K. 46: 627-645

Gray, J. S. (1966b). The response of Protodrilus symbioticus (Giard) (Archannelida) to light. J. Anim. Ecol. 35: 55-64

Gray, J. S. (1967a). Substrate selection by the archiannelid Protodrilus rubropharyngeus. Helgoländer wiss. Meeresunters. 15: 253-269

Gray, J. S. (1967b). Substrate selection by the archiannelid Protodrilus hypoleucas Armenante. J. exp. mar. Biol. Ecol. 1: $47-54$

Gray, J. S. (1968). An experimental approach to the ecology of the harpacticoid Leptastacus constrictus Lang. J. exp. mar. Biol. Ecol. 2: 278-292

Gray, J. S., Johnson, R. M. (1970). The bacteria of a sandy beach as an ecological factor affecting the interstitial gastrotrich Turbanella hyalina Schultze. J. exp. mar. Biol. Ecol. 4: 119-133

Heip, C. (1975). On the significance of aggregation in some benthic marine invertebrates. In: Barnes, H. (ed.) Proc. 9th Eur. Mar. Biol. Symp. Aberdeen University Press, Aberdeen, p. 527-538

Heip, C., Engels, P. (1977). Spatial segregation in copepod species from a brackish-water habitat. J. exp. mar. Biol. Ecol. 81: 47-72

Hogue, E. W. (1978). Spatial and temporal dynamics of a subtidal estuarine gastrotrich assemblage. Mar. Biol. 49: 22

Hopner, T., Wonneberger, K. (1985). Examination of the connection between the patchiness of benthic nutrient efflux and epibenthos patchiness on intertidal flats. Neth. J. Sea Res. 19: 277-285

Jansson, B. O. (1966). Microdistribution of factors and fauna in marine sandy beaches. Veröff. Inst. Meeresforsch. Bremerh., Sonderbd 2: 77-86

Jansson, B. O. (1967). The significance of grain-size and porewater content for the interstitial fauna of sandy beaches. Oikos 18: 311-322

Jansson, B. O. (1968). Quantitative and experimental studies of the interstitial fauna in four Swedish sandy beaches. Ophelia 5: 1-71

Jensen, P. (1984). Food ingestion and growth of the diatomfeeding nematode Chromadorita tenuis. Mar. Biol. 81: 307-310

Jensen, P. (1987). Feeding ecology of free-living aquatic nematodes. Mar. Ecol. Prog. Ser. 35: 187-196

Jumars, P. A., Thistle, D., Jones, M. L. (1977). Detecting twodimensional spatial structure in biological data. Oecologia (Berl.) 28: 109-123

Jumars, P. A. (1978). Spatial autocorrelation with RUM (Remote Underwater Manipulator): vertical and horizontal structure of a bathyal benthic community. Deep-Sea Res. 25: 589-604

Lee, J. J., Lee, M. J. (1979). The growth and reproduction of selected species of meiofauna in selected natural micro- 
floral assemblages. Biol. Bull. mar. biol. Lab., Woods Hole 157: $378-379$

Legendre, L., Legendre, P. (1984). Ecologie numerique. Tome 2: la structure des donnees ecologiques. $2^{\text {eme }}$ ed. Masson, Paris; Presses de l'Universite de Quebec, Quebec

Lorenzen, C. J. (1967). Determination of chlorophyll and pheopigments: spectrophotometric equations. Limnol. Oceanogr. 12 (2): 343-346

Montagna, P. A., Coull. B. C., Herring, T. L., Dubley, B. W. (1983). The relationship between abundances of meiofauna and their suspected microbial food. Estuar. coast. Shelf Sci. 17: 381-394

Montagna, P. A. (1984). In situ measurement of meiobenthic grazing rates on sediment bacteria and edaphic diatoms. Mar. Ecol. Prog. Ser. 18: 119-130

Montagna, P. A., Bauer, J. E. (1988). Partitioning radiolabeled thymidine uptake by bacteria and meiofauna using metabolic blocks and poisons in benthic feeding studies. Mar. Biol. 98: 101-110

Nilsson, P. (1987). Demography of Mesochra lilljeborji and Amonardia normani (Copepoda: Harpacticoida) reared on two diatom diets. Mar. Ecol. Prog. Ser. 39: 267-374

Plante, R., Plante-Cuny, M.-R., Reys, J.-P. (1986). Photosynthetic pigments of sandy sediments on the North Mediterranean coast: their spatial distribution and its effect on sampling strategies. Mar. Ecol. Prog. Ser. 34: $133-141$

Plante-Cuny, M.-R. (1978). Pigments photosynthetiques et production primaire des fonds meubles neritiques d'une region tropicale (Nosy-Be, Madagascar). Trav. Doc. ORSTOM 96: 1-359

Riaux, C., Germain, H. (1980). Peuplements de diatomees epipeliques d'une slikke de Bretagne Nord. Importance relative du genre Cocconeis Ehr. Cryptogamie 1: 265-279

Rieper, M., Flotow, C. (1981). Feeding experiments with bacteria, ciliates and harpacticoid copepods. Kieler Meeresforsch. Sonderh. 5: 370-375

Rieper, M. (1978). Bacteria as food for marine harpacticoid copepods. Mar. Biol. 45 (4): 337-346

This article was submitted to the editor
Schiemer, F. (1982). Food dependence and energetics of freeliving nematodes. II. Life history parameters of Caenorhabditis briggsae (Nematoda) at different levels of food supply. Oecologia (Berl.) 54: 122-128

Schiemer, F., Duncan, A., Klekowski, R. C. (1980). A bioenergetic study of a benthic nematode, Plectus palustris de Man 1880, throughout its life cycle. II. Growth, fecundity and energy budgets at different levels of bacterial food and general ecological considerations. Oecologia (Berl.) 44: 205-212

Sokal, R. R., Oden, N. L. (1978). Spatial autocorrelation in biology. 1. Methodology. Biol. J. Linn. Soc. 10: 199-228

Sokal, R. R., Wartenberg, D. E. (1981). Space and population structure. In: Griffith, D., McKinnon, R. (eds). Dynamic spatial models. Sijthoff and Noordhoff, Alphen aan den Rijn, p. $186-213$

Thistle, D. (1978). Harpacticoid dispersion patterns: implications for deep-sea diversity maintenance. J. mar. Res. 36 (2): 377-397

Tietjen, J. H., Lee, J. J. (1977). Feeding behavior of marine nematodes. In: Coull, B. C. (ed.) Ecology of marine benthos. University of South Carolina Press, Columbia, p. 21-35

Tietjen, J. H., Lee, J. J. (1973). Life history and feeding habits of the marine nematode, Chromadora macrolaimoides Steiner. Oecologia (Berl.) 12: 303-314

Trotter, D. B., Webster, J. M. (1984). Feeding preferences and seasonality of free-living nematodes inhabiting the kelp Macrocystis integrifolia. Mar. Ecol. Prog. Ser. 14: 151-157

Vanden Berghe, W., Bergmans, M. (1981). Differential food preferences in three co-occurring species of Tisbe (Copepoda, Harpacticoida). Mar. Ecol. Prog. Ser. 4: 213-219

Warwick, R. M., Gee, J. M., Berge, J. A., Ambrose, W. Jr. (1984). Effects of the feeding activity of the polychaete Streblosoma bairdi (Malmgren) on meiofaunal abundance and community structure. Sarsia 71: 11-16

Manuscript first received: June 19, 1990

Revised version accepted: August 24, 1990 